\title{
Analogs of Antifungal Indoles Isolated from Aporpium Caryae with Activity against Sudden-Death Syndrome of Soybean
}

\author{
Brenda Bertinetti ${ }^{1}$, Mercedes Scandiani ${ }^{2}$, Gabriela Cabrera ${ }^{1}$ \\ ${ }^{1}$ Organic Chemistry Dept and UMYMFOR (CONICET), Buenos Aires University, Ciudad Universitaria, Buenos Aires, Argentina; \\ ${ }^{2}$ Agricultural Laboratory Río Paraná, San Pedro, Buenos Aires, Argentina. \\ Email: gabyc@qo.fcen.uba.ar
}

Received March $1^{\text {st }}, 2011$; revised April 28 $8^{\text {th }}, 2011$; accepted May $8^{\text {th }}, 2011$.

\begin{abstract}
Based on the precedent discovery of a weak antifungal indole isolated from Aporpium caryae, which increased its activity when changing the $N$-alkyl chain, nineteen $N$-alkyl indoles, with alkyl chains from one to ten carbons and one or two hydroxyls, one amine or bromine functional groups, were prepared and fully characterized by spectroscopic methods. The aim of this study is the search for new synthetic agrochemical leads derived from natural products. The antifungal activity of the synthesized compounds against three fungal strains was measured in vitro. Six compounds presented good activity against Fusarium virguliforme, the causal agent of sudden-death syndrome (SDS) in soybean, in a bioautography assay. Four of them were tested in a germination test and in a greenhouse experiment. All tested compounds, applied as seed treatment, showed antifungal properties being effective to control SDS when there was low level of fungal contamination. Results indicate that some of the tested compounds are acting as growth inhibitors and represent new leads for the treatment of SDS for which no specific treatment has been previously reported.
\end{abstract}

Keywords: N-Alkyl Indole, Soybean Phytopathogen, Fusarium Virguliforme, Sudden-Death Syndrome

\section{Introduction}

Fungal infections are one of the main limiting factors in the production of soybean and other crops, affecting yield, and the quality of seeds and byproducts. Approximately 50 fungal diseases are known, although only some of them are harmful, and only under specific conditions. Among the important fungal pathogens of soybeans are Sclerotinia sclerotiorum (Sclerotinia stem rot), Fusarium virguliforme and F. tucumaniae [1] (suddendeath syndrome, SDS), Cercospora kikuchii (purple seed stain), Colletotrichum truncatum (anthracnose), Macrophomina phaseolina (charcoal rot) and Rhizoctonia solani (damping-off).

Most of the commercial, extended-use fungicides used to control these diseases are simple synthetic compounds with disadvantages, such as their possible contamination of the environment and the introduction of risks to worker health [2-4].

The development of sustainable alternatives to synthetic fungicides has attracted growing interest as the use of natural products. Some examples of natural microbial agrochemicals are griseofulvin, isolated from Penicillium griseofulvum, cycloheximide, isolated from Streptomyces griseus, strobilurin A, isolated from Strobilurus tenacellus and oudemansin A, isolated from Oudemansiella mucida [5].

The use of microorganisms to produce agrochemicals has been limited [6], mainly because agrochemical use requires large amounts of product, and because of the comparative costs of producing simple synthetic compounds versus cultured natural products. Even though the low-cost production of natural agrochemicals by fermentation cannot be achieved in many cases, the use of these compounds as templates for the production of synthetic agrochemicals derived from natural products is a viable alternative, as in the case of strobilurins. Strobilurin A and oudemansin A were the lead compounds in the development of azoxystrobin from Zeneca and kresoximmethyl from Basf, which are employed as fungicides for several crops [7].

In this context, the goal of this study was the discovery of new leads based on a weakly antifungal indole, iso- 
lated from Aporpium caryae and designated compound $\mathbf{1}$ [8].

In this work, we describe the performance in antifungal activity tests of new synthetic analogs of $\mathbf{1}$.

\section{Materials and Methods}

\subsection{General Procedures}

Optical rotation was recorded on a Perkin Elmer polarimeter 343. FTIR spectra were recorded on a Nicolet Magna-IR 550. NMR spectra were recorded on a Bruker Avance II instrument at $500.13 \mathrm{MHz}$ for ${ }^{1} \mathrm{H}$ (referenced to TMS, $\delta=0$ ) and at $125.13 \mathrm{MHz}$ for ${ }^{13} \mathrm{C}$ NMR (referenced to the center line of $\mathrm{CDCl}_{3}, \delta$ 77.0). High performance liquid chromatography used a variable-wavelength UV detector coupled with a refractive index detector (RefractoMonitor IV, Thermo Separation Products). Accurate ESI MS was carried out on a Bruker MicrOTOF-Q II, whereas EIMS employed a mass spectrometer Trio-2 VG Masslab (Manchester, UK). All chemicals were purchased from standard commercial suppliers. Methyl 3-indole-carboxylate was purchased from Acros Organics and all the alkyl halides (including (R)-(-)-3-chloro-1,2-propanediol and (S)-(+)-3-chloro1,2-propanediol) were purchased from Sigma-Aldrich.

\subsection{Bioassays}

\subsubsection{Bioautography on Silicagel}

Direct bioautography on TLC was employed as a method for detecting fungitoxic substances [9,10]. Fusarium virguliforme O'Donnell \& T. Aoki NRRL 34551, Fusarium lateritium Nees ex Link (BAFC 759), Macrophomina phaseolina (Tassi) Goid (BAFC 3428) and Botrytis cinerea Pers.: Fr. (BAFC 535) were employed as fungal targets.

A concentration level of $50 \mu \mathrm{g} / \mathrm{spot}$ of each assayed compound was used. Benomyl and Maxim ${ }^{\circledR}$ XL (50 $\mu \mathrm{g}$ of total fludioxonil plus metalaxyl active ingredients), were used as test compounds. Benomyl was tested at a conc. level of $25 \mu \mathrm{g} / \mathrm{spot}$. When big inhibitory halos were observed, minimum inhibitory concentrations (MIC) were measured by the same method [9]. The experiments were repeated 3 times or 5 times for the most active compounds.

\subsubsection{Seed Treatment}

Soybean untreated seeds $(50 \mathrm{~g})$ were treated with an aqueous suspension (Tween 80, 2 drops; water, $0.5 \mathrm{ml}$ ) of the test compound $(100 \mathrm{mg})$ with agitation for $60 \mathrm{sec}-$ onds. These treated (C) seeds were employed in the bioassays.

For a positive control, the abovementioned treatment was repeated employing Maxim XL (fludioxonyl + metalaxyl, $0.1 \mathrm{ml}$ ) instead of test compound. These treated (M) seeds were employed in the following bioassays.

\subsubsection{Germination Test in the Laboratory. Blotter Paper Technique}

400 treated $(\mathrm{C})$, treated $(\mathrm{M})$ and untreated seeds $(\mathrm{U})$ were used to estimate seed fungal incidence of pathogens [11] and compound efficacy.

The seeds were plated on trays $(16 \times 20 \times 5 \mathrm{~cm}, 50$ seeds per tray) and incubated at $25^{\circ} \mathrm{C} \pm 1{ }^{\circ} \mathrm{C}$ under alternating periods of $12 \mathrm{~h}$ fluorescent cool daylight (Osram $18 \mathrm{~W} / 765)$ for 7 days [12]. The seeds were then examined under stereomicroscope at 40x magnification and the identification of the fungi was based on the presence of conidiophores and conidia of the pathogen at $20-40 x$ [13]. The experiment was repeated three times.

Data from this experiment were subjected to analysis of variance (ANOVA). Treatment means were compared by least significant differences at $P=0.05$.

\subsubsection{Greenhouse Experiment}

Ninety eight disinfected untreated seeds and ninety eight treated (C) seeds were added to pots containing field soil and covered with another $2 \mathrm{~cm}$ of soil. Half of them were inoculated with Fusarium virguliforme NRRL 34551 [1]. Pots were then placed on a greenhouse bench and grown under natural photoperiod at $25^{\circ} \mathrm{C} \pm 2^{\circ} \mathrm{C}$ for 4 - 5 weeks. Soil was watered to saturation after planting and maintained at near field capacity throughout the study.

Plants were rated for incidence of SDS-like symptoms on the foliage, plant height and shoot fresh weight. Disease incidence (DI) of plants was based on the percentage of plants with foliar symptoms typical of SDS [1].

Symptoms ranged from leaf curling and rugosity, marginal cupping, mottling, chlorotic interveinal spots, interveinal chlorosis and necrosis, to leaf drop and stunting.

Foliar disease severity (DS) was rated during 5 weeks after planting based on a scale of 1 to 5 , where $1=$ no symptoms; 2 = light symptom development with mottling and mosaic $(1 \%-20 \%$ foliage affected); $3=$ moderate symptom development with interveinal chlorosis and necrosis $(21 \%-50 \%$ foliage affected); $4=$ heavy symptom development $(51 \%-80 \%$ foliage affected $)$; and $5=$ severe symptom development with interveinal chlorosis and necrosis and/or dead plants $(81 \%-100 \%$ foliage affected) [14].

At the end of the experiment, all plants were rated for height and the fresh shoot weight was determined. Data from this experiment were subjected to analysis of variance (ANOVA). Treatment means were compared by 
least significant differences at $P=0.05$. The experiment was repeated three times.

\section{Results and Discussion}

During the structural elucidation of indole derivatives from Aporpium caryae [8], compounds 7 and 8 were prepared to compare the sign of the optical rotation and the absolute stereochemistry. Their antifungal activity against the phytopathogen Cladosporium cucumerinum was weak, although higher than the natural compound 1. For this reason, a new set of indole derivatives (Figure 1) with a variety of $N$-alkyl chains was prepared to explore the antifungal activity of this type of compound against fungal strains of economical importance for soybean production. The preparation of these compounds was easily achieved in basic media using the corresponding alkyl halide (Suppl. Mat.). All compounds were purified, fully characterized and structurally assigned by $1 \mathrm{D}$ and 2D NMR (HSQC, HMBC, COSY) and mass spectrometry (Suppl. Mat.). To the best of our knowledge, compounds 3-13, 16 and 18-20 have not been previously isolated or described. Compound $\mathbf{1 5}$ was claimed in a patent as an intermediate in the synthesis of triazoles [15], and compounds 2 and $\mathbf{1 7}$ were previously reported as a by-product and an intermediate, respectively, in the synthesis of alkyl indoles [16,17].

As a preliminary step in detecting antifungal properties,

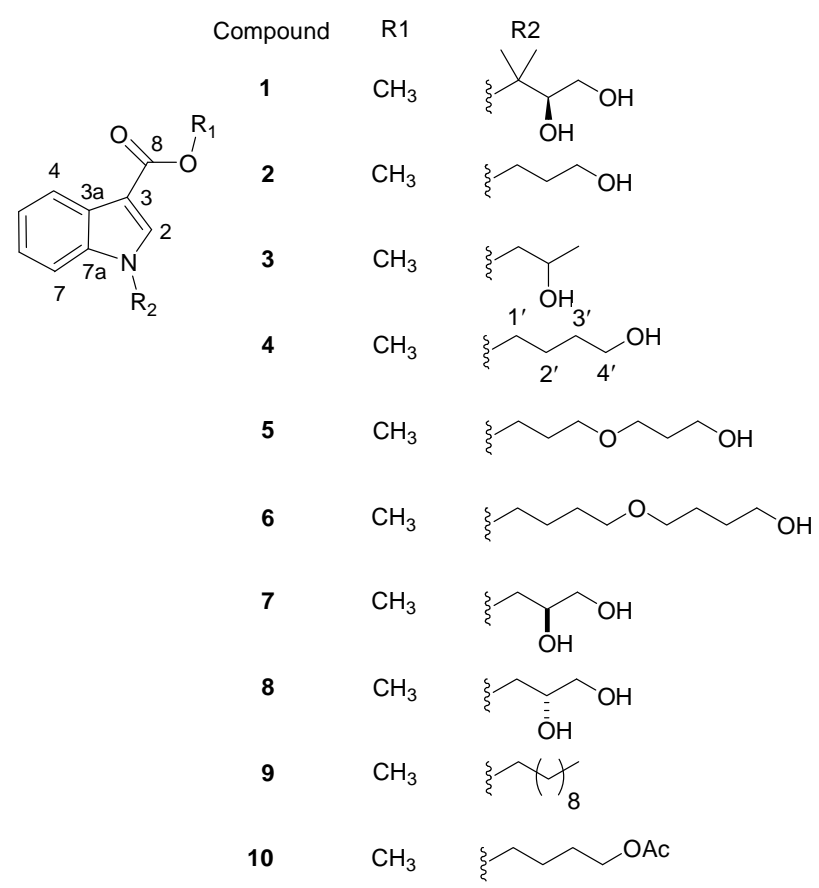

the effect of each compound was evaluated in an in vitro test against three fungal species, $F$. virguliforme, F. lateritium and $M$. phaseolina. These species represent strains of significant economic importance, and they generally have different responses to antifungal compounds. As stated above, F.virguliforme is one of the causal agents of SDS in soybeans, and M. phaseolina causes charcoal rot; F. lateritium is a phytopathogen of Cucurbitaceae. Botrytis cinerea, a phytopathogen of grapevine, was also tested in some cases. The antifungal activity of the synthesized compounds is presented in Table 1. Compounds 2-4, 10, 14 and 17 showed antifungal activity in this screen against $F$. virguliforme, $F$. lateritium and M. phaseolina. Their inhibitory halos were from 10 to $17 \mathrm{~mm}$ but since halo diameter is dependent on diffusion and other physical properties of the compounds, the absolute value may be not very relevant. The minimum inhibitory concentration (MIC) [9] for compounds $2,3,4$ and 10 against $F$. virguliforme was 5 $\mu \mathrm{g} /$ point.

The results in Table 1 also indicated that for these derivatives the presence of three to four carbon atoms with only one hydroxyl group in the alkyl chain attached to the indole nitrogen led to strongly positive result. The presence of a larger chain in $\mathbf{9}$ or a bulky chain in $\mathbf{2 0}$ caused a complete loss of activity. The results with compounds 4, 16 and 18 (Table 1) indicated that the

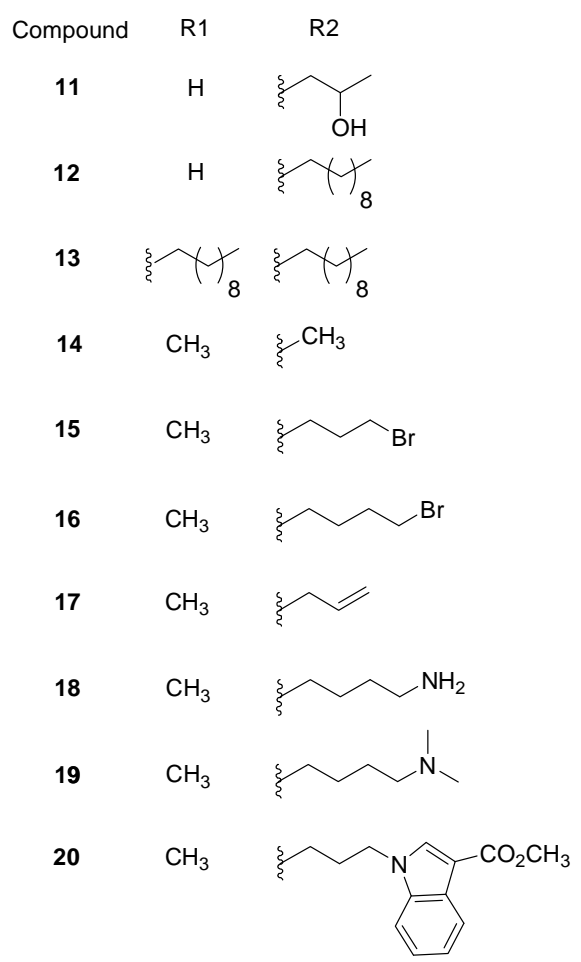

Figure 1. Tested compounds. 
Table 1. Antifungal activities of synthetic compounds 2 - 20.

\begin{tabular}{|c|c|c|c|c|}
\hline Compound & Fusarium virguliforme & Fusarium lateritium & Macrophomina phaseolina & Botrytis cinerea \\
\hline 2 & $17+/-2(5)$ & $16+/-2(5)$ & $22+/-1$ & $19+/-1$ \\
\hline 3 & $15+/-1(5)$ & $12+/-2(5)$ & - & $6+/-1$ \\
\hline 4 & $17+/-2(5)$ & $12+/-2(5)$ & $15+/-2$ & $20+/-2$ \\
\hline 5 & - & $6+/-1$ & $10+/-1$ & $4+/-1$ \\
\hline 7 & $3+/-1$ & - & $14+/-1$ & - \\
\hline 8 & $4+/-1$ & - & $4+/-2$ & - \\
\hline 9 & - & - & $10+/-1$ & - \\
\hline 10 & $14+/-2(5)$ & $16+/-2(5)$ & $16+/-2$ & nd \\
\hline 11 & - & - & - & - \\
\hline 12 & $7+/-1$ & - & - & $7+/-1$ \\
\hline 13 & - & - & - & - \\
\hline 14 & $10+/-1$ & $13+/-1$ & $15+/-1$ & nd \\
\hline 15 & $5+/-1$ & $9+/-1$ & $9+/-1$ & nd \\
\hline 16 & $5+/-1$ & $8+/-1$ & $9+/-1$ & nd \\
\hline 17 & $11+/-1$ & $15+/-1$ & $17+/-2$ & nd \\
\hline 18 & - & - & - & nd \\
\hline 19 & $5+/-1$ & $7+/-1$ & $10+/-1$ & nd \\
\hline 20 & - & - & - & nd \\
\hline Benomyl & $27+/-2$ & $30+/-1$ & $30+/-2$ & $25+/-1$ \\
\hline Maxim XL & $12+/-2$ & $12+/-1$ & $18+/-1$ & nd \\
\hline
\end{tabular}

Diameter of inhibition zone in mm (MIC $\mu \mathrm{g} / \mathrm{pt}$ ). $50 \mu \mathrm{g} /$ spot was used except benomyl ( $25 \mu \mathrm{g} / \mathrm{spot}$ ); nd: not determined.

replacement of the hydroxyl group by a primary amine or bromine resulted in a loss of activity against all strains. Initially, compound $\mathbf{6}$ gave approximately the same results as 4, and NMR showed that 6 decomposed rapidly to 4 . Therefore, 6 was not further examined and is not shown in Table 1. The responses of the tested compounds against F.virguliforme and $F$. lateritium were similar, but some differences were observed when activeties against $M$. phaseolina and B. cynerea were compared. For example, compound 3 was inactive or weakly active, and 7, 14 and 17 gave more activity against these strains than against the Fusarium species.

Four of the active compounds, 2, 4, 10 and 14 were selected for further analysis.

A germination test was performed, in order to determine the fungal incidence of pathogens [11] and compound efficacy on natural contaminated seeds. The use of different seed batches also allows the comparison of diverse natural situations, with dissimilar type and degree of pathogen contamination. The incidence of fungal infection in untreated seeds and seeds treated with the selected compounds is shown in Table 2, and the frequency of fungal pathogens is listed in Table 3.

Table 2. Effect of compound 2, 4, 10 and 14 on fungal incidence $(\%)$.

\begin{tabular}{cc}
\hline Treatment & $\%$ incidence \\
\hline $\mathrm{U}$ & $41.7 \mathrm{a}$ \\
$\mathrm{C} 2$ & $13.4 \mathrm{~b}$ \\
$\mathrm{C} 4$ & $9.8 \mathrm{~b}$ \\
$\mathrm{C} 10$ & $19.9 \mathrm{~b}$ \\
$\mathrm{C} 14$ & $13.8 \mathrm{~b}$ \\
$\mathrm{M}$ & $2.5 \mathrm{c}$ \\
\hline
\end{tabular}

$\mathrm{U}=$ untreated soybean seeds, $\mathrm{Cx}=$ treated soybean seeds with compound $\mathbf{x}$, $\mathrm{M}=$ treated soybean seeds with Maxim XL, SD ranged from 0.3 to 1.1 ( $\mathrm{n}=$ 4) Values within a column followed by the same letter are not significantly different. Tukey analysis test at $P=0.05$. 
Table 3. Effect of compounds on frequency (\%) of pathogens.

\begin{tabular}{cccccc}
\hline Treatment & Fusarium spp. $^{\mathrm{i}}$ & Phomopsis spp. $^{\mathrm{i}}$ & Fusarium spp. $^{\mathrm{ii}}$ & Phomopsis sp. $^{\mathrm{ii}}$ & Cercospora kikuchii $^{\mathrm{iii}}$ \\
\hline $\mathrm{U}$ & $26.5 \mathrm{a}$ & $7.8 \mathrm{a}$ & $81.9 \mathrm{a}$ & $28.8 \mathrm{a}$ & $6.7 \mathrm{a}$ \\
$\mathrm{C} 2$ & $4.9 \mathrm{c}$ & $3.5 \mathrm{ab}$ & $64.9 \mathrm{~b}$ & $9.3 \mathrm{~d}$ & $3.5 \mathrm{a}$ \\
$\mathrm{C} 4$ & $2.7 \mathrm{~cd}$ & $3.5 \mathrm{ab}$ & $71.0 \mathrm{ab}$ & $10.9 \mathrm{bcd}$ & $6.9 \mathrm{a}$ \\
$\mathrm{C} 10$ & $10.6 \mathrm{~b}$ & $4.3 \mathrm{a}$ & $61.1 \mathrm{~b}$ & $6.7 \mathrm{a}$ & $5.2 \mathrm{a}$ \\
$\mathrm{C} 14$ & $6.9 \mathrm{bc}$ & $5.3 \mathrm{a}$ & $62.0 \mathrm{~b}$ & $19.4 \mathrm{ab}$ & $6.3 \mathrm{a}$ \\
$\mathrm{M}$ & $0.0 \mathrm{~d}$ & $0.9 \mathrm{~b}$ & $33.9 \mathrm{c}$ & $10.0 \mathrm{~cd}$ & $0.4 \mathrm{~b}$ \\
\hline
\end{tabular}

i-iii experiments using different seed batches, $\mathrm{U}=$ untreated soybean seeds, $\mathrm{Cx}=$ treated soybean seeds with compound $\mathbf{x}, \mathrm{M}=$ treated soybean seeds with Maxim XL, SD ranged from 0.1 to $1.2(\mathrm{n}=4)$, Values within a column followed by the same letter are not significantly different. Tukey analysis test at $P=$ 0.05 .

Significant differences were observed between the untreated seeds (treatment U, Table 2), which showed a high percent of fungal incidence $(41.7 \%+/-0.6 \%)$, seeds treated with any of the tested compounds 2, 4, 10 or 14, which showed from $9.8 \%$ to $19.9 \%$ (treatment $\mathrm{Cx}$ ), and seeds treated with Maxim XL, which showed the smallest percentage of fungal incidence $(2.5 \%+/-0.4 \%$, treatment $\mathrm{M}$ ). There were no significant differences between the tested compounds. When the frequency of fungal pathogens was analyzed, some differences were observed, depending on the pathogen. Compounds 2, 4, 10 or 14 showed to be effective in the inhibition of Fusarium spp. with different significance between them, being the order 4, 2, 14, 10 from higher to smaller response (Table 3). The tendency was less pronounced against Phomopsis spp. and a lack of activity was observed in the case of the pathogen Cercospora kikuchii. When the seed batch was naturally very contaminated (Table $\mathbf{3}$, entries ii), the same tendency remains although the percentages of frequency were high. Furthermore, compound 2 was as active as Maxim in this situation.

Other fungal pathogens were also present although their frequency was too small to be statistically considered.

All these results would indicate that compounds 2, 4, 10 and 14 are acting as fungal growth inhibitors. This outcome is in accordance with other studies which have reported that indoles like indole-3-acetic acid possess fungistatic activity [18]; at the same time, indole also has been shown to act synergistically with other known antifungal compounds to enhance their fungistatic properties [19].

A greenhouse experiment was performed with these compounds to see their effect on the incidence of SDS on soybean plants inoculated with Fusarium virguliforme (Suppl. Mat., Table 1). All the tested compounds prevented plant infection comparing with plants derived from untreated seeds $(95 \%+/-2 \%$ infected $)$. It is noteworthy that the infected plants had light symptoms of foliar disease severity, with a development of chlorotic mottling as the main infection.

In another experiments, which resulted in a more severe global infection, carried out only with 2 , it was shown that this compound did not affect plant growth, and both height and fresh shoot weight of treated plants were not significantly different from untreated plants (Table 4). A significant difference in height and fresh shoot weights were seen between seeds inoculated with $F$. virguliforme and left untreated $(\mathrm{U}+F v)$, compared to those treated with compound $2(\mathrm{C}+F v)$. The percentage of incidence of SDS for $U+F v$ was very high $(85 \% \pm$ $2 \%$ ) from the first 15 dpi (days post-inoculation) to the last measurement at $35 \mathrm{dpi}(90 \% \pm 2 \%)$, while in the case of $\mathrm{C}+F v$ a $48 \% \pm 4 \%$ incidence at $15 \mathrm{dpi}$ and $67 \% \pm 4 \%$ incidence at 35 dpi (Table 5) was observed. This difference is especially important when the severity results are included (Figure 2), because the severity factor at $35 \mathrm{dpi}$ was near 5 for $U+F v$, and less than 3 for $C+F v$. These results are in full agreement with previous tests and support the conclusion that compound 2 has a clear effect on the incidence of $F$. virguliforme on soybean plants.

It is noteworthy that a good correlation between the in vitro antifungal test using bioautography and the other tests was observed in this work, probably because all the compounds belong to the same structural family and have similar physical properties.

As there are few data in the literature related to the control of SDS, the results achieved in this work may not be deeply compared with other works. In general, there were no studies showing remarkable performance for preventing SDS in soybean. For example the oligosac-

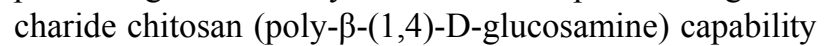
to prevent SDS on soybean caused by Fusarium solani was evaluated in greenhouse experiments [20]. Chitosan 
Table 4. Effect of compound 2 on height and fresh shoot weight of soybean plants inoculated with Fusarium virguliforme under greenhouse conditions.

\begin{tabular}{ccc}
\hline \multicolumn{3}{c}{ Height and fresh shoot weight } \\
\hline Treatment & Height $(\mathrm{cm})$ & fresh shoot weight $(\mathrm{g})$ \\
\hline $\mathrm{U}$ & $94+/-2 \mathrm{a}$ & $11+/-1 \mathrm{a}$ \\
$\mathrm{C} 2$ & $90+/-2 \mathrm{a}$ & $12+/-2 \mathrm{a}$ \\
$\mathrm{U}+F v$ & $22+/-2 \mathrm{c}$ & $1.4+/-0.2 \mathrm{c}$ \\
$\mathrm{C} 2+F v$ & $31+/-5 \mathrm{~b}$ & $4+/-1 \mathrm{~b}$ \\
\hline
\end{tabular}

$\mathrm{U}=$ untreated soybean seeds, $\mathrm{C} 2=$ treated soybean seeds with compound 2 , $F v=$ inoculation with Fusarium virguliforme, Values within a column followed by the same letter are not significantly different. Tukey analysis test at $P=0.05$.

Table 5. Effect of compound 2 on incidence of Sudden-death syndrome (SDS) on soybean plants inoculated with Fusarium virguliforme under greenhouse conditions.

\begin{tabular}{cccccc}
\hline \multicolumn{5}{c}{ Incidence (\%) } \\
\hline Treatment & 15 dpi & 18 dpi & 24 dpi & 32 dpi & 35 dpi \\
$U+F v$ & $85 \pm 2$ & $85 \pm 2$ & $90 \pm 2$ & $90 \pm 2$ & $90 \pm 2$ \\
$C+F v$ & $48 \pm 4$ & $63 \pm 5$ & $63 \pm 5$ & $67 \pm 4$ & $67 \pm 4$ \\
\hline
\end{tabular}

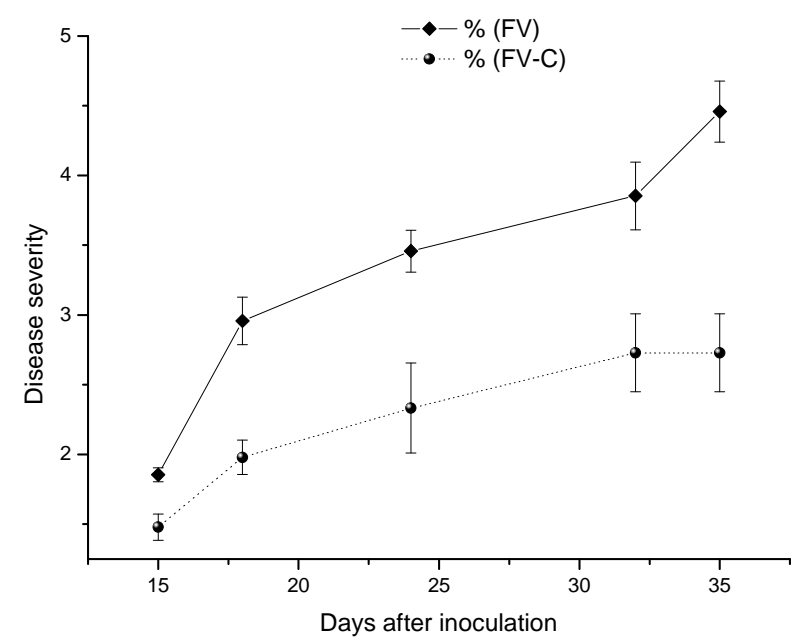

Figure 2. Effect of compound 2 on foliar severity of Sudden-death syndrome (SDS) on soybean plants inoculated with Fusarium virguliforme under greenhouse conditions.

showed certain ability to retard the SDS symptom expression in soybean leaves but it could not absolutely protect the soybean from disease incidence. Strobilurins, which are known fungicides used in crop protection, were examined in field experiments in combination with potassium chloride [21]. These studies revealed that strobilurin fungicide treatments showed variable effects on the severity of SDS disease and no significant yield response to foliar application was displayed. It is worth mentioning that the present work is the first one where the activity of compounds against Fusarium virguliforme is investigated and no similar studies about SDS in soybean caused by this phytopathogen were found.

\section{Conclusions}

In summary, nineteen analogs of the natural compound $\mathbf{1}$ were prepared, characterized and screened for antifungal activity. Six analogs, designated 2-4, 10, 14 and 17, were determined to have antifungal activity against $F$. virguliforme in vitro and 2, 4, 10 and 14 also when applied as seed treatments. Their antifungal activity is dependent on the degree of contamination, being more effective in the first period of infection or when low pathogen content is present, and is more selective against Fusarium spp. These substances represent new leads for the treatment of SDS, for which no specific treatment has been reported, and for which commercial fungicides have only limited effects [22] and eventually would be useful for the development of a combination treatment with known fungicides, as a strategy to reduce their widespread use.

\section{Acknowledgements}

We thank Universidad de Buenos Aires (X029), ANPCYT and CONICET for financial support and CONICET for the fellowship to BVB.

\section{REFERENCES}

[1] A. Takayuki, K. O’Donnell and M. M. Scandiani, "Sudden-Death Syndrome of Soybean in South America is Caused by Four Species of Fusarium: Fusarium Brasiliense Sp. Nov., F. Cuneirostrum Sp. Nov., F. Tucumaniae, and F. Virguliforme," Mycoscience, Vol. 46, No. 3, 2005, pp. 162-183. doi:10.1007/s10267-005-0235-y

[2] M. Bjørling-Poulsen, H. R. Andersen and P. Grandjean, "Potential Developmental Neurotoxicity of Pesticides Used in Europe," Environmental Health, Vol. 7, No. 1, 2008, pp. 1-22.

[3] E. Hodgson and R. Rose, "Metabolic Interactions of Agrochemicals in Humans," Pest Management Science, Vol. 64, No. 6, 2008, pp. 617-621. doi:10.1002/ps.1563

[4] M. F. Simoniello, E. C. Kleinsorge, J. A. Scagnetti, R. A. Grigolato, G. L. Poletta and M. A. Carballo, "DNA Damage in Workers Occupationally Exposed to Pesticide Mixtures," Journal of Applied Toxicology, Vol. 28, 2008, pp. 957-965.

[5] Y. Tanaka, "Antifungal Agents," In: S. Omura, Ed., The Search for Bioactive Compounds from Microorganisms, Springer-Verlag Inc., New York, 1992, pp. 31-44.

[6] D. M. Gibson and S. B. Krasnoff, "Exploring the Potential of Biologically Active Compounds from Plants and 
Fungi," In: H. G. Cutler and S. J. Cutler, Eds., Biologically Active Natural Products: Agrochemicals, CRC Press, Boca Raton, 1999, pp. 231-242.

doi:10.1201/9781420048629.ch20

[7] H. L. Ypema and R. E. Gold, "Kresoxim-Methyl, Modification of a Naturally Occurring Compound to Produce a New Fungicide," Plant Disease, Vol. 83, No. 1, 1999, pp. 4-19. doi:10.1094/PDIS.1999.83.1.4

[8] L. M. Levy, G. M. Cabrera, J. E. Wright and A. M. Seldes, "Indole Alkaloids from the Culture of the Fungus Aporpium Caryae," Phytochem, Vol. 54, No. 8, 2000, pp. 941-943. doi:10.1016/S0031-9422(00)00127-8

[9] F. Hadacek and H. Greger, "Testing of Antifungal Natural Products: Methodologies, Comparability of Results and Assay Choice," Phytochemical Analysis, Vol. 11, No. 3, 2000, pp. 137-147.

[10] A. L. Homans and A. Fuchs, "Direct Bioautography on Thin-Layer Chromatography as a Method for Detecting Fungitoxic Substances," Journal of Chromatography, Vol. 51, No. 2, 1970, pp. 325-328.

doi:10.1002/(SICI) 1099-1565(200005/06)11:3<137::AID -PCA514>3.0.CO;2-I

[11] D. Sharma-Poudyal, E. Duveiller and R. C. Sharma, "Effects of Seed Treatment and Foliar Fungicides on Helminthosporium Leaf Blight and on the Performance of Wheat in Warmer Growing Conditions," Journal of Phytopathology, Vol. 153, No. 7-8, 2005, pp. 401-408. doi:10.1111/j.1439-0434.2005.00992.x

[12] C. Leach, 1963. "The Qualitative and Quantitative Relationship of Monochromatic Radiation to Sexual and Asexual Reproduction of Pleospora herbarum," Mycologia, Vol. 55, No. 2, 1963, pp. 151-163. doi: $10.2307 / 3756286$

[13] M. M. Scandiani and A. G. Luque, "Identificación de Patógenos en Semilla de Soja," In: G. Rolando, Ed., Suplemento Especial N2, Análisis de Semillas, Estudio Rolando, Rosario, 2009, pp. 1-148.

[14] Y. H. Huang and G. L. Hartman, "Reaction of Selected Soybean Genotypes to Isolates of Fusarium Solani F. Sp.
Glycines and Their Culture Filtrates," Plant Disease, Vol. 82, No. 9, 1998, pp. 999-1002. doi:10.1094/PDIS.1998.82.9.999

[15] K. Karabelas, M. Lepisto and P. Sjo, "Preparation of New Triazoles as Pharmaceutically Active Compounds Activity as Kinase Inhibitors,” Appl. US 2000, 646972.

[16] M. Ishikura, W. Ida and K. Yanada, "A One-Pot Access to Cycloalkano [1,2-A]Indoles through an Intramolecular Alkyl Migration Reaction in Indolylborates," Tetrahedron, Vol. 62, No. 5, 2006, pp. 1015-1024. doi:10.1016/j.tet.2005.10.045

[17] F. Ziegler and L. O. Jeroncic, "A New Route to 9,9aDihydro-3H-Pyrrolo[1,2-A]Indoles via Radical Cyclization," Journal of Organic Chemistry, Vol. 56, No. 42, 1991, pp. 3479-3486. doi:10.1021/jo00011a008

[18] Q. Yue and C. J. Miller, J. F. White and M. Richardson, "Isolation and Characterization of Fungal Inhibitors from Epichloë Festucae," Journal of Agricultural and Food Chemistry, Vol. 48, No. 10, 2000, pp. 4687-4692. doi:10.1021/jf990685q

[19] M. Himejima and I. Kubo, "Fungicidal Activity of Polygodial in Combination with Anethole and Indole against Candida Albicans," Journal of Agricultural and Food Chemistry, Vol. 41, No. 10, 1993, pp. 1776-1779. doi: 10.1021/jf00034a048

[20] B. Prapagdee, K. Kotchadat, A. Kumsopa and N. Visarathanonth, "The Role of Chitosan in Protection of Soybean from Sudden Death Syndrome Caused by Fusarium Solani F. sp. Glycines," Bioresource Technology, Vol. 98, No. 7, 2007, pp. 1353-1358. doi:10.1016/j.biortech.2006.05.029

[21] K. A. Nelson, P. P. Motavalli, W. E. Stevens, D. Dunn and C. G. Meinhardt, "Soybean Response to Preplant and Foliar-Applied Potassium Chloride with Strobilurin Fungicides," Agronomy Journal, Vol. 102, No. 6, 2010, pp. 1657-1663. doi:10.2134/agronj2010.0065

[22] G. E. Shaner, D. H. Scott and T. S. Abney, "SuddenDeath Syndrome in Soybeans," 2004. http://www.ces.purdue.edu/extmedia/BP/BP-58.pdf. 


\section{APPENDIX}

\section{Preparation of the $N$-Alkylindoles}

The $N$-alkylindoles 2-4, 7-10, 15, 16 and 20 were prepared by treatment of methyl 3-indole-carboxylate with $\mathrm{NaH}$ in THF or DMSO, and subsequent substitution of the corresponding alkyl halides. Typical conditions were as follows: to a solution of methyl 3-indole-carboxylate $(200 \mathrm{mg}, 1.14 \mathrm{mmol})$ in dry DMSO (2ml), 2 eq. $\mathrm{NaH}$ were added and the mixture was stirred for about $20 \mathrm{~min}$ utes until it turned green-colored. The alkyl chloride (1.2eq) was then added drop wise to the resulting solution. The mixture was stirred overnight at room temperature. Methanol was used to remove the excess of hydride, water was added and the products were extracted with ethyl acetate $(3 \times 5 \mathrm{ml})$. After concentration in vacuo, the residue was purified by HPLC RP-18. Yields obtained were between 40 to $95 \%$.

Compounds 5, 6, 11, 12-13 and 17 were obtained as minor by-products, in the preparation of 2, 4, 3, 9 and 15 respectively, and were separated by HPLC (YMC C18, 5 $\mu \mathrm{m}, 22.5 \times 2.5 \mathrm{~cm}, \mathrm{MeOH}-\mathrm{H}_{2} \mathrm{O} 6: 4(5,11), \mathrm{MeOH}-\mathrm{H}_{2} \mathrm{O}$ $7: 3(6,17)$ or preparative TLC (silicagel, cyclohexane$\mathrm{CH}_{2} \mathrm{Cl}_{2}$ 1:1)(12, 13). Compounds 18 (and 19) were prepared by treatment of $\mathbf{1 6}$ with $\mathrm{NH}_{3}$ (or dimethyl amine).

\section{Spectroscopical Data of Previously Undescribed Compounds}

Compound 3. 1-(2-Hydroxy-propyl)-1H-indole-3-carboxylic acid methyl ester

Oil. IR (KBr, cm $\left.{ }^{-1}\right) v_{\max }: 3453(\mathrm{OH}), 2937(\mathrm{CH}), 1677$ $(\mathrm{C}=\mathrm{O}) .{ }^{1} \mathrm{H}$ NMR $\left(\mathrm{CDCl}_{3}\right)$ : d $8.04(\mathrm{~m}, 1 \mathrm{H}, \mathrm{H}-4) ; 7.75$ (s, $1 \mathrm{H}, \mathrm{H}-2) ; 7.27$ (m, 1H, H-7); 7.16 (m, 2H, H-5,6); 4.10 (m, 1H, H-2'); 4.04 (dd, $J=14.4$ and $3.9 \mathrm{~Hz}, 1 \mathrm{H}, \mathrm{H}-1^{\prime}$ ); $3.92\left(\mathrm{dd}, J=14.4\right.$ and $\left.7.7 \mathrm{~Hz}, 1 \mathrm{H}, \mathrm{H}-1^{\prime}\right) ; 3.69$ (s, 3H, $\left.\mathrm{CH}_{3} \mathrm{O}\right) ; 2.40$ (brs, $\left.1 \mathrm{H}, \mathrm{OH}\right) ; 1.16(\mathrm{~d}, J=6.2 \mathrm{~Hz}, 3 \mathrm{H}$, $\mathrm{H}-3$ '). ${ }^{13} \mathrm{C}$ NMR $\left(\mathrm{CDCl}_{3}\right)$ : d $165.5(\mathrm{C}-8) ; 136.8(\mathrm{C}-7 \mathrm{a})$; 135.2 (C-2); 126.5 (C-3a); 122.7, 121.9 (C-5, C-6); 121.7 (C-4); 110.0 (C-7); 107.1 (C-3); 66.6 (C-2'); 54.0 (C-1'); $50.9\left(\mathrm{CH}_{3} \mathrm{O}\right) ; 20.6$ (C-3'). HR ESI-MS m/z: 234.1119 $[\mathrm{M}+\mathrm{H}]^{+}$(calcd for $\mathrm{C}_{13} \mathrm{H}_{16} \mathrm{NO}_{3}, 234.1125$, D $2.4 \mathrm{ppm}$ ). EIMS (70 eV): m/z (\%) $233[\mathrm{M}]^{+}(52), 202$ (15), 188 (100), 130 (43).

Compound 4. 1-(4-Hydroxy-butyl)-1H-indole-3-carboxylic acid methyl ester

Oil. IR (KBr, $\left.\mathrm{cm}^{-1}\right) v_{\max }: 3408(\mathrm{OH}), 2951(\mathrm{CH}), 2876$ $(\mathrm{CH}), 1696(\mathrm{C}=\mathrm{O}) .{ }^{1} \mathrm{H}$ NMR $\left(\mathrm{CDCl}_{3}\right)$ : d $8.16(\mathrm{~m}, 1 \mathrm{H}$, H-4); 7.81 (s, 1H, H-2); 7.34 (m, 1H, H-7); 7.25 (m, 2H, $\mathrm{H}-5,6) ; 4.13$ (t, $J=7.1 \mathrm{~Hz}, 2 \mathrm{H}, \mathrm{H}-1$ '); 3.88 (s, 3H, $\left.\mathrm{CH}_{3} \mathrm{O}\right) ; 3.60\left(\mathrm{t}, J=6.2 \mathrm{~Hz}, 2 \mathrm{H}, \mathrm{H}-4^{\prime}\right) ; 1.96\left(\mathrm{~m}, 2 \mathrm{H}, \mathrm{H}-2^{\prime}\right)$; 1.63 (brs, $1 \mathrm{H}, \mathrm{OH}) ; 1.55$ (m, 2H, H-3'). ${ }^{13} \mathrm{C}$ NMR $\left(\mathrm{CDCl}_{3}\right)$ : d 165.6 (C-8); 136.4 (C-7a); 134.2 (C-2); 126.6
(C-3a); 122.6, 121.7, 121.6 (C-4, C-5, C-6); 109.9 (C-7); 106.7 (C-3); 61.8 (C-4'); $50.7\left(\mathrm{CH}_{3} \mathrm{O}\right) ; 46.6\left(\mathrm{C}^{\prime} 1^{\prime}\right) ; 29.6$ (C-3'); 26.3 (C-2'). HR ESI-MS $m / z$ : $248.1207[\mathrm{M}+\mathrm{H}]^{+}$ (calcd for $\mathrm{C}_{14} \mathrm{H}_{18} \mathrm{NO}_{3}, 248.1281$, D 2.9 ppm). EIMS (70 $\mathrm{eV}): \mathrm{m} / \mathrm{z}(\%) 247[\mathrm{M}]^{++}(100), 216$ (27), 188 (86), 144 (50).

Compound 5. 1-[3-(3-Hydroxy-propoxy)-propyl]- 1Hindole-3-carboxylic acid methyl ester

Oil. IR (KBr, cm $\left.{ }^{-1}\right) v_{\max }: 3417(\mathrm{OH}), 2928(\mathrm{CH}), 1696$ $(\mathrm{C}=\mathrm{O}), 1105(\mathrm{C}-\mathrm{O}-\mathrm{C}) .{ }^{1} \mathrm{H}$ NMR $\left(\mathrm{CDCl}_{3}\right): \mathrm{d} 8.17(\mathrm{~m}, 1 \mathrm{H}$, H-4); 7.84 (s, 1H, H-2); 7.38 (m, 1H, H-7); 7.27 (m, 2H, $\mathrm{H}-5,6) ; 4.29$ (t, $J=6.6 \mathrm{~Hz}, 2 \mathrm{H}, \mathrm{H}-1$ '); 3.91 (s, $3 \mathrm{H}$, $\left.\mathrm{CH}_{3} \mathrm{O}\right) ; 3.81\left(\mathrm{dd}, J=6.1,5.0 \mathrm{~Hz}, 2 \mathrm{H}, \mathrm{H}-7^{\prime}\right) ; 3.56(\mathrm{t}, J=$ $5.70 \mathrm{~Hz}, 2 \mathrm{H}, \mathrm{H}-3^{\prime}$ ) ; 3.33 (t, $J=5.70 \mathrm{~Hz}, 2 \mathrm{H}, \mathrm{H}-5$ '); 2.15 (brs, 1H, OH); 2.11 (m, 2H, H-2'); 1.86 (m, 2H, H-6'). ${ }^{13} \mathrm{C}$ NMR $\left(\mathrm{CDCl}_{3}\right)$ : d $165.6(\mathrm{C}-8) ; 136.5(\mathrm{C}-7 \mathrm{a}) ; 134.6$ (C-2); 126.7 (C-3a); 122.7, 121.9, 121.8 (C-4, C-5, C-6); 109.9 (C-7); 107.1 (C-3); 69.7, 67.1 (C-5', C-7'); 61.4 $\left(\mathrm{C}-3^{\prime}\right) ; 50.9\left(\mathrm{CH}_{3} \mathrm{O}\right) ; 43.5$ (C-1'); 32.2 (C-2'); 29.8 (C-6'). EIMS (70 eV): m/z (\%) $291[\mathrm{M}]^{+*}(60), 260$ (7), 189 (76), 188 (39), 130 (100).

Compound 6. 1-[4-(4-Hydroxy-butoxy)-butyl]-1H-indole3-carboxylic acid methyl ester

Oil. IR $\left(\mathrm{KBr}, \mathrm{cm}^{-1}\right) v_{\max }: 3431(\mathrm{OH}), 2945(\mathrm{CH}), 2862$ $(\mathrm{CH}), 1699(\mathrm{C}=\mathrm{O}) .{ }^{1} \mathrm{H}$ NMR $\left(\mathrm{CDCl}_{3}\right): \mathrm{d} 8.18(\mathrm{~m}, 1 \mathrm{H}$, $\mathrm{H}-4) ; 7.85$ (s, 1H, H-2); 7.37 (m, 1H, H-7); 7.27 (m, 2H, $\mathrm{H}-5,6) ; 4.19$ (t, $J=7.1 \mathrm{~Hz}, 2 \mathrm{H}, \mathrm{H}-1$ '); 3.91 (s, 3H, $\mathrm{CH}_{3} \mathrm{O}$ ); 3.64 (dd, $J=11.0 \mathrm{~Hz}$ and $5.6 \mathrm{~Hz}, 2 \mathrm{H}, \mathrm{H}-9^{\prime}$ ); 3.43 (m, 4H, H-4' y 6'); 2.20 (brs, $1 \mathrm{H}, \mathrm{OH}) ; 1.97$ (m, 2H, $\left.\mathrm{H}-2^{\prime}\right) ; 1.66$ (m, 4H, H-7', 8'); $1.60\left(\mathrm{~m}, 2 \mathrm{H}, \mathrm{H}-3^{\prime}\right) .{ }^{13} \mathrm{C}$ NMR (CDCl $)$ : d 165.6 (C-8); 136.4 (C-7a); 134.2 (C-2); 126.6 (C-3a); 122.6, 121.7, 121.6 (C-4, C-5, C-6); 109.9 (C-7); 106.7 (C-3); 71.0 (C-6'); 70.3 (C-4'); 62.8 (C-9'); 62.8 (C-9'); $50.9\left(\mathrm{CH}_{3} \mathrm{O}\right) ; 46.6\left(\mathrm{C}-1{ }^{\prime}\right) ; 30.3\left(\mathrm{C}-7^{\prime}\right) ; 26.9$ (C-2', C-3'); 26.7 (C-8'). HR ESI-MS m/z: 320.1866 $[\mathrm{M}+\mathrm{H}]^{+}$(calcd for $\mathrm{C}_{18} \mathrm{H}_{26} \mathrm{NO}_{4}, 320.1856$, D -3.0 ppm). EIMS (70 eV): m/z (\%) $319[\mathrm{M}]^{+}(39), 216$ (37), 188 (100), 172 (73), 130 (83).

Compound 7. (S) 1-(2,3-Dihydroxy-propyl)-1H-indole -3-carboxylic acid methyl ester

$\mathrm{Mp} 108^{\circ} \mathrm{C}-110^{\circ} \mathrm{C} .[\mathrm{a}]_{\mathrm{D}}{ }^{25}=-20$ (c $\left.0.4, \mathrm{MeOH}\right)$. IR $\left(\mathrm{KBr}, \mathrm{cm}^{-1}\right) v_{\max }: 3459(\mathrm{OH}), 2900(\mathrm{CH}), 1674(\mathrm{C}=\mathrm{O})$. ${ }^{1} \mathrm{H}$ NMR $\left(\mathrm{CDCl}_{3}\right)$ : d $8.02(\mathrm{~m}, 1 \mathrm{H}, \mathrm{H}-4) ; 7.79(\mathrm{~s}, 1 \mathrm{H}, \mathrm{H}-2)$; 7.29 (m, 1H, H-7); 7.16 (m, 2H, H-5, 6); 4.15 (dd, $J=$ 14.4 and $4.8 \mathrm{~Hz}, 1 \mathrm{H}, \mathrm{H}-1^{\prime}$ ); 4.03 (dd, $J=14.4$ and $7.3 \mathrm{~Hz}$, 1H, $\left.\mathrm{H}-1^{\prime}\right) ; 3.94$ (m, 1H, H-2'); 3.72 (s, 3H, $\left.\mathrm{CH}_{3} \mathrm{O}\right) ; 3.53$ (dd, $J=11.4$ and $3.9 \mathrm{~Hz}, 1 \mathrm{H}, \mathrm{H}-3^{\prime}$ ); 3.38 (dd, $J=11.4$ and $5.7 \mathrm{~Hz}, 1 \mathrm{H}, \mathrm{H}-3$ '); 3.05 (brs, $1 \mathrm{H}, \mathrm{OH}) .{ }^{13} \mathrm{C}$ NMR $\left(\mathrm{CDCl}_{3}\right)$ : d $165.6(\mathrm{C}-8) ; 136.8$ (C-7a); 135.2 (C-2); 126.6 (C-3a); 123.0, 122.1, 121.8 (C-4, C-5, C-6); 109.9 (C-7); 107.5 (C-3); $70.6\left(\mathrm{C}-2^{\prime}\right) ; 63.7\left(\mathrm{C}-3^{\prime}\right) ; 51.0\left(\mathrm{CH}_{3} \mathrm{O}\right) ; 49.1$ (C-1'). HR ESI-MS $m / z$ : $250.1061[\mathrm{M}+\mathrm{H}]^{+}$(calcd for 
$\mathrm{C}_{13} \mathrm{H}_{16} \mathrm{NO}_{4}, 250.1074$, D $\left.5.2 \mathrm{ppm}\right)$. EIMS $(70 \mathrm{eV}): \mathrm{m} / \mathrm{z}$ (\%) $249[\mathrm{M}]^{+}$(63), 218 (20), 189 (22), 188 (100), 130 (24).

Compound 8. (R) 1-(2,3-Dihydroxy-propyl)-1H-indole -3-carboxylic acid methyl ester

$\mathrm{Mp} 109^{\circ} \mathrm{C}-110^{\circ} \mathrm{C} .[\mathrm{a}]_{\mathrm{D}}^{25}=16(\mathrm{c} 0.4, \mathrm{MeOH}) . \mathrm{IR}(\mathrm{KBr}$, $\left.\mathrm{cm}^{-1}\right) v_{\max }: 3459(\mathrm{OH}), 2910(\mathrm{CH}), 1674(\mathrm{C}=\mathrm{O}) .{ }^{1} \mathrm{H}$ NMR $\left(\mathrm{CDCl}_{3}\right)$ : d $8.06(\mathrm{~m}, 1 \mathrm{H}, \mathrm{H}-4) ; 7.86(\mathrm{~s}, 1 \mathrm{H}, \mathrm{H}-2)$; 7.37 (m, 1H, H-7); 7.21 (m, 2H, H-5, 6); 4.25 (dd, $J=$ 14.4 and $\left.5.0 \mathrm{~Hz}, 1 \mathrm{H}, \mathrm{H}-1^{\prime}\right) ; 4.10(\mathrm{dd}, J=14.4$ and $7.3 \mathrm{~Hz}$, $1 \mathrm{H}, \mathrm{H}-1^{\prime}$ ); 3.97 (m, 2H, H-2'); 3.83 (s, 3H, $\mathrm{CH}_{3} \mathrm{O}$ ); 3.55 (dd, $J=11.4$ and $4.3 \mathrm{~Hz}, 1 \mathrm{H}, \mathrm{H}-3$ '); 3.43 (dd, $J=11.4$, $5.5 \mathrm{~Hz}, 1 \mathrm{H}, \mathrm{H}-3$ '); 3.05 (brs, $1 \mathrm{H}, \mathrm{OH}) .{ }^{13} \mathrm{C}$ NMR $\left(\mathrm{CDCl}_{3}\right)$ : d 166.0 (C-8); 136.8 (C-7a); 135.5 (C-2); 126.4 (C-3a); 122.7, 121.8, 121.4 (C-4, C-5, C-6); 110.0 (C-7); 106.8 (C-3); 70.3 (C-2'); 63.4 (C-3'); $50.9\left(\mathrm{CH}_{3} \mathrm{O}\right)$; $49.0\left(\mathrm{C}-1^{\prime}\right)$. HR ESI-MS $m / z: 250.1078[\mathrm{M}+\mathrm{H}]^{+}$(calcd for $\mathrm{C}_{13} \mathrm{H}_{16} \mathrm{NO}_{4}$, 250.1074, D -1.7 ppm). EIMS (70 eV): m/z (\%) 249 $[\mathrm{M}]^{+\cdot}(52), 218$ (12), 189 (18), 188 (100), 130 (13).

Compound 9. 1-Decyl-1H-indole-3-carboxylic acid methyl ester

Oil. IR (KBr, cm $\left.{ }^{-1}\right) v_{\max }: 2920(\mathrm{CH}), 2851(\mathrm{CH}), 1702$ $(\mathrm{C}=\mathrm{O}) .{ }^{1} \mathrm{H}$ NMR $\left(\mathrm{CDCl}_{3}\right)$ : d $8.10(\mathrm{~m}, 1 \mathrm{H}, \mathrm{H}-4) ; 7.74(\mathrm{~s}$, 1H, H-2); 7.28 (m, 1H, H-7); 7.19 (m, 2H, H-5, 6); 4.04 (t, $J=7.3 \mathrm{~Hz}, 2 \mathrm{H}, \mathrm{H}-1$ '); 3.83 (s, $3 \mathrm{H}, \mathrm{CH}_{3} \mathrm{O}$ ); 1.78 (qi, $J$ $\left.=7.1 \mathrm{~Hz}, 2 \mathrm{H}, \mathrm{H}-2^{\prime}\right) ; 1.15-1.23\left(\mathrm{~m}, 14 \mathrm{H}, \mathrm{H}-3\right.$ ' to $\left.9^{\prime}\right) ; 0.80$ (t, $J=6.8 \mathrm{~Hz}, 3 \mathrm{H}, \mathrm{H}-10$ '). ${ }^{13} \mathrm{C}$ NMR $\left(\mathrm{CDCl}_{3}\right): \mathrm{d} 165.5$ (C-8); 136.6 (C-7a); 134.2 (C-2); 126.7 (C-3a); 122.6, 121.7 (C-4, C-5, C-6); 109.9 (C-7); 106.9 (C-3); 50.9 $\left(\mathrm{CH}_{3} \mathrm{O}\right) ; 47.0$ (C-1'); 31.8 (C-2'); 29.8, 29.5, 29.4, 29.2, 29.1, 26.8, 22.6 (C-3' to $\left.\mathrm{C}-9^{\prime}\right)$; 14.1 (C-10'). HR ESI-MS $m / z: 316.2261[M+\mathrm{H}]^{+}$(calcd for $\mathrm{C}_{20} \mathrm{H}_{30} \mathrm{NO}_{2}, 316.2271$, D $3.1 \mathrm{ppm})$. EIMS (70 eV): m/z (\%) $315[\mathrm{M}]^{+}(100), 284$ (18), 188 (64), 130 (42).

Compound 10. 1-(4-Acetoxy-butyl)-1H-indole-3- carboxylic acid methyl ester

Oil. IR $\left(\mathrm{KBr}, \mathrm{cm}^{-1}\right) v_{\max }: 2954(\mathrm{CH}), 1735(\mathrm{C}=\mathrm{O})$, $1696(\mathrm{C}=\mathrm{O}), 1241(\mathrm{C}-\mathrm{O}) .{ }^{1} \mathrm{H}$ NMR $\left(\mathrm{CDCl}_{3}\right): \mathrm{d} 8.20(\mathrm{t}$, $1 \mathrm{H}, \mathrm{H}-4) ; 7.82$ (s, 1H, H-2); 7.34 (t, 1H, H-7); 7.29 (m, 2H, H-5, 6); 4.19 (t, $\left.J=7.0 \mathrm{~Hz}, 2 \mathrm{H}, \mathrm{H}-1^{\prime}\right) ; 4.06$ (t, $J=$ $\left.6.4 \mathrm{~Hz}, 2 \mathrm{H}, \mathrm{H}-4^{\prime}\right) ; 3.92\left(\mathrm{~s}, 3 \mathrm{H}, \mathrm{CH}_{3} \mathrm{O}\right) ; 2.03$ (s, 3H, $\mathrm{CH}_{3} \mathrm{CO}$ ); 1.92 (qi, $J=7.0 \mathrm{~Hz}, 2 \mathrm{H}, \mathrm{H}-2$ ) $) 1.63(\mathrm{~m}, 2 \mathrm{H}$, $\mathrm{H}-3$ '). ${ }^{13} \mathrm{C}$ NMR $\left(\mathrm{CDCl}_{3}\right)$ : d $170.9\left(\mathrm{CH}_{3} \mathrm{CO}\right) ; 165.3(\mathrm{C}-8)$; 136.4 (C-7a); 134.2 (C-2); 126.7 (C-3a); 122.7, 121.8, 121.7 (C-4, C-5, C-6); 109.9 (C-7); 106.9 (C-3); 63.7 (C-4'); $51.1\left(\mathrm{CH}_{3} \mathrm{O}\right)$; 46.6 (C-1'); 26.7, 26.1 (C-2', C-3'); $20.9\left(\mathrm{CH}_{3} \mathrm{CO}\right)$. HR ESI-MS m/z: $290.1403[\mathrm{M}+\mathrm{H}]^{+}$ (calcd for $\mathrm{C}_{16} \mathrm{H}_{20} \mathrm{NO}_{4}, 290.1387$, D -4.53 ppm). EIMS $(70 \mathrm{eV}): \mathrm{m} / \mathrm{z}(\%) 289[\mathrm{M}]^{+*}(99), 258$ (27), 188 (100), 144 (22).

Compound 11. 1-(2-Hydroxy-propyl)-1H-indole -3carboxylic acid
$\mathrm{Mp} 150^{\circ} \mathrm{C}-151^{\circ} \mathrm{C}$. IR $\left(\mathrm{KBr}, \mathrm{cm}^{-1}\right) v_{\max }: 3342(\mathrm{OH})$, $2923(\mathrm{CH}), 1549.1(\mathrm{C}=\mathrm{O}) .{ }^{1} \mathrm{H}$ NMR $\left(\mathrm{CDCl}_{3}-\mathrm{CD}_{3} \mathrm{OD} 5 \%\right)$ : d 8.20 (m, 1H, H-4); 7.73 (s, 1H, H-2); 7.36 (m, 1H, H-7); 7.12 (m, 2H, H-5, 6); 4.13 (m, 2H, H-2'); 4.10 (m, 2H, $\left.\mathrm{H}-1^{\prime}\right) ; 1.16\left(\mathrm{~d}, J=6.0 \mathrm{~Hz}, 3 \mathrm{H}, \mathrm{H}-3^{\prime}\right) .{ }^{13} \mathrm{C} \mathrm{NMR}$ $\left(\mathrm{CDCl}_{3}-\mathrm{CD}_{3} \mathrm{OD} 5 \%\right)$ : d 174.1 (C-8); 138.1 (C-7a); 134.6 (C-2); 128.6 (C-3a); 122.7, 122.4, 121.2 (C-4, C-5, C-6); 114.1 (C-3); 110.5 (C-7); 67.3 (C-2'); 54.4 (C-1'); 20.9 (C-3'). HR ESI-MS $m / z$ : $220.0979[\mathrm{M}+\mathrm{H}]^{+}$(calcd for $\mathrm{C}_{12} \mathrm{H}_{14} \mathrm{NO}_{3}, 220.0968$, D -4.8 ppm). EIMS (70 eV): m/z (\%) $219[\mathrm{M}]^{+}$(27), 175(35), 174 (39), 130 (100).

Compound 12. 1-Decyl-1H-indole-3-carboxylic acid

$\mathrm{Mp} 87^{\circ} \mathrm{C}-88^{\circ} \mathrm{C}$. IR $\left(\mathrm{KBr}, \mathrm{cm}^{-1}\right) v_{\max }: 3239(\mathrm{OH}), 2917$ $(\mathrm{CH}), 1663(\mathrm{C}=\mathrm{O}) .{ }^{1} \mathrm{H}$ NMR $\left(\mathrm{CDCl}_{3}\right): \mathrm{d} 8.13(\mathrm{~m}, 1 \mathrm{H}$, $\mathrm{H}-4) ; 7.80$ (s, 1H, H-2); 7.27 (m, 1H, H-7); 7.18 (m, 2H, H-5, 6); 4.02 (t, $J=7.1 \mathrm{~Hz}, 2 \mathrm{H}, \mathrm{H}-1$ '); 1.76 (qi, $J=7.1$ $\mathrm{Hz}, 2 \mathrm{H}, \mathrm{H}-2$ '), 1.15-1.23 (m, 14H, H-3' to H-9'); 0.78 (t, $\left.J=6.8 \mathrm{~Hz}, 3 \mathrm{H}, \mathrm{H}-10{ }^{\prime}\right) .{ }^{13} \mathrm{C}$ NMR $\left(\mathrm{CDCl}_{3}\right): \mathrm{d} 168.9(\mathrm{C}-8)$; 136.6 (C-7a); 135.1 (C-2); 126.9 (C-3a); 122.6, 121.8, 121.7 (C-4, C-5, C-6); 109.9 (C-7); 106.3 (C-3); 46.9 (C-1'); 31.7 (C-2'); 29.7, 29.3, 29.3, 29.1, 29.0, 26.7, 22.5 (C-3' to $\left.\mathrm{C}^{\prime} 9^{\prime}\right)$; 13.9 (C-10'). HR ESI-MS $\mathrm{m} / \mathrm{z}$ : $302.2128[\mathrm{M}+\mathrm{H}]^{+}$(calcd for $\mathrm{C}_{19} \mathrm{H}_{28} \mathrm{NO}_{2}, 302.2115$, D $-4.6 \mathrm{ppm})$. EIMS (70 eV): m/z (\%) $301[\mathrm{M}]^{+*}(100), 256$ (14), 174 (80), 130 (56).

Compound 13. 1-Decyl-1H-indole-3-carboxylic acid decyl ester

Oil. IR (KBr, cm $\left.{ }^{-1}\right) v_{\max }: 2929(\mathrm{CH}), 1707(\mathrm{C}=\mathrm{O}) .{ }^{1} \mathrm{H}$ NMR $\left(\mathrm{CDCl}_{3}\right)$ : d $8.17(\mathrm{~m}, 1 \mathrm{H}, \mathrm{H}-4) ; 7.82(\mathrm{~s}, 1 \mathrm{H}, \mathrm{H}-2)$; 7.36 (m, 1H, H-7); 7.26 (m, 2H, H-5, 6); 4.32 (t, $J=6.6$ $\left.\mathrm{Hz}, 2 \mathrm{H}, \mathrm{H}-1^{\prime}{ }^{\prime}\right) ; 4.13$ (t, $\left.J=7.3 \mathrm{~Hz}, 2 \mathrm{H}, \mathrm{H}-1^{\prime}\right) ; 1.80-1.87$ (m, 4H, H-2', 2' '); $1.25-1.47$ (m, 28H, H-3' to H-9', $\mathrm{H}-3$ "' to H-9"'); 0.88 (t, $J=7.3 \mathrm{~Hz}, 3 \mathrm{H}, \mathrm{H}-10$ '*); 0.87 (t, $J=7.1 \mathrm{~Hz}, 3 \mathrm{H}, \mathrm{H}-10, *) .{ }^{13} \mathrm{C}$ NMR $\left(\mathrm{CDCl}_{3}\right): \mathrm{d} 165.4$ (C-8); 136.6 (C-7a); 134.2 (C-2); 126.7 (C-3a); 122.5, 121.8, 121.7 (C-4, C-5, C-6); 109.9 (C-7); 107.3 (C-3); 63.9 (C-4'); 47.0 (C-1'); 31.9, 29.9, 29.5, 29.3, 29.2, 29.0, 26.9, 22.7 (C-3' to C-9', C-3"' to C-9''); 14.1 (C-10', C-10"'). HR ESI-MS $m / z$ : 442.3689 [M+H] ${ }^{+}$(calcd for $\mathrm{C}_{29} \mathrm{H}_{48} \mathrm{NO}_{2}, 442.3680$, D -2.1 ppm). EIMS (70 eV): m/z (\%) $441[\mathrm{M}]^{+}(100), 301$ (17), 284 (23), 174 (15), 130 (13).* may be interchanged.

Compound 16. 1-(4-Bromo-butyl)-1H-indole-3-carboxylic acid methyl ester

Oil. IR (KBr, cm $\left.{ }^{-1}\right) v_{\max }: 2942(\mathrm{CH}), 1691(\mathrm{C}=\mathrm{O}), 747$ (CBr). ${ }^{1} \mathrm{H}$ NMR $\left(\mathrm{CDCl}_{3}\right)$ : d $8.18(\mathrm{~m}, 1 \mathrm{H}, \mathrm{H}-4) ; 7.82(\mathrm{~s}$, 1H, H-2); 7.37 (m, 1H, H-7); 7.29 (m, 2H, H-5, 6); 4.20 $\left(\mathrm{t}, J=6.9 \mathrm{~Hz}, 2 \mathrm{H}, \mathrm{H}-1^{\prime}\right) ; 3.91$ (s, $\left.3 \mathrm{H}, \mathrm{CH}_{3} \mathrm{O}\right) ; 3.39$ (t, $J=$ $\left.6.5 \mathrm{~Hz}, 2 \mathrm{H}, \mathrm{H}-4^{\prime}\right) ; 2.06$ (m, 2H, H-2'); 1.88 (m, 2H, $\mathrm{H}-3$ '). ${ }^{13} \mathrm{C}$ NMR $\left(\mathrm{CDCl}_{3}\right)$ : d 165.6 (C-8); 136.6 (C-7a); 134.1 (C-2); 126.9 (C-3a); 123.0, 122.1 (C-5, C-6); 122.0 (C-4); 109.9 (C-7); 107.4 (C-3); $51.2\left(\mathrm{CH}_{3} \mathrm{O}\right) ; 46.3$ 
(C-1'); 32.8 (C-4'); 29.9 (C-3'); 28.6 (C-2'). HR ESI-MS $m / z: 310.0440[\mathrm{M}+\mathrm{H}]^{+}$(calcd for $\mathrm{C}_{14} \mathrm{H}_{17} \mathrm{BrNO}_{2}, 310.0437$, D -0.9 ppm). EIMS $(70 \mathrm{eV}): \mathrm{m} / \mathrm{z}(\%) 311[\mathrm{M}+2]^{+}(48)$, $309[\mathrm{M}]^{+}(44), 280$ (13), 278 (13), 188 (100), 55 (49).

Compound 18. 1-(4-Amino-butyl)-1H-indole-3-carboxylic acid methyl ester

Oil. IR $\left(\mathrm{KBr}, \mathrm{cm}^{-1}\right) v_{\max }: 3459,3423\left(\mathrm{NH}_{2}\right), 2917(\mathrm{CH})$, $1680(\mathrm{C}=\mathrm{O}) .{ }^{1} \mathrm{H}$ NMR $\left(\mathrm{CDCl}_{3}-\mathrm{CD}_{3} \mathrm{OD} 5 \%\right)$ : $8.14(\mathrm{~m}$, 1H, H-4); 7.88 (s, 1H, H-2); 7.39 (m, 1H, H-7); 7.29 (m, $2 \mathrm{H}, \mathrm{H}-5,6) ; 4.24$ (t, $J=6.8 \mathrm{~Hz}, 2 \mathrm{H}, \mathrm{H}-1$ '); 3.91 (s, 3H, $\mathrm{CH}_{3} \mathrm{O}$ ); 2.90 (t, $\left.J=7.6 \mathrm{~Hz}, 2 \mathrm{H}, \mathrm{H}-4^{\prime}\right) ; 1.97$ (m, 2H, H-2'); 1.68 (m, 2H, H-3'). ${ }^{13} \mathrm{C}$ NMR $\left(\mathrm{CDCl}_{3}-\mathrm{CD}_{3} \mathrm{OD} 5 \%\right)$ : d 165.9 (C-8); 136.2 (C-7a); 134.4 (C-2); 126.4 (C-3a); 123.1, 122.2 (C-5, C-6); 121.9 (C-4); 110.0 (C-7); 106.9 (C-3); $51.2\left(\mathrm{CH}_{3} \mathrm{O}\right)$; 46.2 (C-1'); 39.4 (C-4'); 26.8 (C-2'); 25.2 (C-3'). HR ESI-MS m/z: 247.1449 [M+H] $]^{+}$(calcd for $\mathrm{C}_{14} \mathrm{H}_{19} \mathrm{~N}_{2} \mathrm{O}_{2}, 247.1441$, D -3.0 ppm). EIMS (70 eV): $\mathrm{m} / \mathrm{z}(\%) 246[\mathrm{M}]^{++}(15), 214$ (16), 188 (21), 144 (36), 43 (100).

Compound 19. 1-(4-Dimethylamino-butyl)-1H-indole3-carboxylic acid methyl ester

Oil. IR $\left(\mathrm{KBr}, \mathrm{cm}^{-1}\right) v_{\max }$ : $2942(\mathrm{CH}), 1702(\mathrm{C}=\mathrm{O}) .{ }^{1} \mathrm{H}$ NMR (CDCl $)$ : d 8.18 (m, 1H, H-4); 7.83 (s, 1H, H-2); 7.37 (m, 1H, H-7); 7.28 (m, 2H, H-5, 6); 4.18 (t, $J=7.1$
$\mathrm{Hz}, 2 \mathrm{H}, \mathrm{H}-1^{\prime}$ ); 3.91 (s, 3H, $\mathrm{CH}_{3} \mathrm{O}$ ); 2.40 (t, $J=7.5 \mathrm{~Hz}$, 2H, H-4'); 2.27 (s, 6H, NCH $H_{3}$ ); 1.91 (m, 2H, H-2'); 1.55 (m, 2H, H-3'). ${ }^{13} \mathrm{C}$ NMR $\left(\mathrm{CDCl}_{3}\right)$ : d $165.6(\mathrm{C}-8) ; 136.6$ (C-7a); 134.3 (C-2); 126.9 (C-3a); 122.9, 122.0 (C-5, C-6); 121.9 (C-4); 110.0 (C-7); $107.2(\mathrm{C}-3) ; 51.1\left(\mathrm{CH}_{3} \mathrm{O}\right)$; 58.3 (C-4'); 46.9 (C-1'); $44.7\left(\mathrm{NCH}_{3}\right) ; 27.7$ (C-2'); 24.3 (C-3'). HR ESI-MS $m / z$ : 275.1741 [M+H] ${ }^{+}$(calcd for $\mathrm{C}_{16} \mathrm{H}_{23} \mathrm{~N}_{2} \mathrm{O}_{2}, 275.1754$, D $\left.4.7 \mathrm{ppm}\right)$. EIMS $(70 \mathrm{eV}): \mathrm{m} / \mathrm{z}$ (\%) $274[\mathrm{M}]^{+*}$ (4), 188 (2), 58 (100).

Compound 20. 1,3-di-[(3'-methoxycarbonyl)-1H -indol1-yl] propane

Mp $176^{\circ} \mathrm{C}-177^{\circ} \mathrm{C}$. IR $\left(\mathrm{KBr}, \mathrm{cm}^{-1}\right) v_{\max }: 2920(\mathrm{CH})$, $1691(\mathrm{C}=\mathrm{O}) .{ }^{1} \mathrm{H}$ NMR $\left(\mathrm{CDCl}_{3}\right)$ : d $8.20(\mathrm{~m}, 2 \mathrm{H}, \mathrm{H}-4)$; 7.76 (s, 2H, H-2); 7.29 (m, 2H, H-5); 7.26 (m, 2H, H-6); 7.19 (m, 2H, H-7); 4.16 (t, $J=6.9$ Hz, 4H, H-1'); 3.91 (s, $\left.6 \mathrm{H}, \mathrm{CH}_{3} \mathrm{O}\right) ; 2.50$ (qi, $J=6.9 \mathrm{~Hz}, 2 \mathrm{H}, \mathrm{H}-2$ ').

${ }^{13} \mathrm{C}$ NMR $\left(\mathrm{CDCl}_{3}\right)$ : d $165.4(\mathrm{C}-8) ; 136.4(\mathrm{C}-7 \mathrm{a}) ; 133.8$ (C-2); 126.9 (C-3a); 123.3 (C-6); 122.4 (C-5); 122.2 (C-4); 109.8 (C-7); 107.9 (C-3); $51.2\left(\mathrm{CH}_{3} \mathrm{O}\right) ; 43.9$ (C-1'); 29.8 (C-2'). HR ESI-MS $m / z$ : $391.1669[\mathrm{M}+\mathrm{H}]^{+}$ (calcd for $\mathrm{C}_{23} \mathrm{H}_{23} \mathrm{~N}_{2} \mathrm{O}_{4}, 391.1652$, D -4.2 ppm). EIMS (70 $\mathrm{eV}): \mathrm{m} / \mathrm{z}(\%) 390[\mathrm{M}]^{+}(24), 359$ (6), 189 (50), 188 (15), $130(100)$. 